\title{
E-LEARNING AND ITS APPLICATION TO PdF UP OLOMOUC
}

\section{Milan KLEMENT - Jiří DOSTÁL}

\begin{abstract}
The present article presents some aspects of the use of e-Learning in the combined forms of study at the Faculty of Palacky University in Olomouc. Describes the long-term development in this area and shows how vital it may have an e-Learning in increasing the efficiency of learning process. Individual outcomes are the result of long-term data collection and statistical evaluation, the main technique used was analysis of data obtained from the economic, educational and management information systems UP Olomouc. Increasing the effectiveness of the learning process, while maintaining the high quality of education provided, at the time of a change in the funding of public universities, particularly important.
\end{abstract}

Key words: distance learning, full-time studies, combined studies, e-learning, LMS.

\section{E-LEARNING A JEHO UPLATNĚNÍ NA PdF UP OLOMOUC}

Resumé: Předložený článek představuje některé aspekty použití e-Learningu v rámci kombinovaných forem studia na Pedagogické fakultě UP Olomouc. Popisuje dlouhodobý vývoj v této oblasti a ukazuje, jaký zásadni vliv může mít e-Learning při zvyšováni efektivnosti výukového procesu. Jednotlivé výstupy jsou výsledkem dlouhodobého sběru dat a jejich statistického vyhodnocení, kdy hlavní použitou metodou byla analýzy dat získaných z ekonomických, studijních a ř́dících informačních systémů UP Olomouc. Zvyšování efektivnosti výukového procesu, se zachováním vysoké kvality poskytovaného vzdělání, je v době zásadnich změn ve financování veřejných vysokých škol, zvláště důležité.

Klíčová slova: distanční vzdělávání, prezenční studium, kombinované studium, e-learning, LMS.

\section{1 Úvod}

Česká republika, jako jeden ze signatářů Boloňské deklarace (1), se zavázala k plnění závazků, vyplývajících z Boloňského procesu, jehož výsledkem má být ucelený Evropský prostor vysokoškolského vzdělávání.

$\mathrm{V}$ rámci tohoto procesu tedy česká republika přistoupila, na základě Berlínského komuniké (2), k restrukturalizaci studijních oborů realizovaných na vysokých školách. Tato restrukturalizace se tedy dotkla všech studijních oborů realizovaných v Č́R s výjimkou některých technických a lékařských studijních oborů. Cílem této restrukturalizace bylo, mimo jiné, zvýšit podíl vysokoškolsky vzdělané populace, nebot' ČR ve srovnání s ostatními zeměmi evropské unie vykazovala jedno z nejnižších čísel.

Celá řada škol $v$ rámci tohoto procesu začala masivně nabízet také kombinované formy svých studijních oborů, nebot' jedním z podstatných faktorů financování vysokých škol byl počet studentů a to bez ohledu na formu studia (3). Jednou z podmínek akreditace kombinovaných studijních oborů, bylo doporučení akreditační komise ČR, že minimálně $30 \%$ celkového rozsahu výuky musí být realizováno distanční formou výuky (4).

Také pedagogická fakulta Univerzity Palackého začala od roku 2006 cíleně podporovat aktivity směřující $\mathrm{k}$ rozšsiřrení počtu akreditovaných studijních oborů v kombinované formě. Jako základní prostředek pro realizaci distančních forem výuky byl použit LMS systém Unifor a jako základní realizační metoda byl zvolen e-learning (5) a (6). Dříve než prisstoupíme $\mathrm{k}$ prezentaci dosažených výsledků a zhodnocení celkového stavu realizace distančních forem výuky na PdF UP Olomouc, zmíníme se nejprve o dvou posledních pojmech a jejich chápání $\mathrm{v}$ rámci fakulty.

\section{E-learning}

České vysoké školství, není již dále schopné tradiční cestou generovat vyšší počty absolventů, protože jinak by mohlo dojít k degradaci kvality vzdělávání. Jako vhodnou variantou se proto jeví využití moderních forem vzdělávání, jako je např́íklad distanční výuky s využitím e-learningu.

E-learning tedy vychází z obecného modelu distanční vzdělávání (DiV), které je definováno jako: „Distanční forma studia neprobíhá 
kontinuálně a není bezprostředně spojena sdohledem vyučujícího. Je založena na plánování, poradenství a výuce sorganizaci tutoriáli̊. Charakteristickým znakem distančního studia je nezávislost neboli autonomie učení. Proto je tato forma studia ve velké míre závislá na didaktickém zpracování materiálů, které musí nahrazovat interakci mezi studujicim a vyučujícím vklasickém kontaktním studiu. Efektivní studium je podporováno průběžným tutorováním a poradenským systémem, který by měl být poskytován $v$ regionálních a mistních studijnich centrech a rozšiřován prostřednictvím moderních komunikačních technologii" (7).

Pojem e-learning se stručně objevuje ve 3 . rozšířeném vydání pedagogického slovníku (Průcha, Walterová, Mareš, 2001): "e-learning Termín se u nás uživá v této anglické podobě nebo $v$ prekladu jako "elektronické učenívzděláváni". Označuje různé druhy učení podporovaného počitačem, zpravidla s využitím modernich technologických prostředkü, predevším CD-ROM" (8).

Tato definice je i v dnešní době platná, nicméně je nutné mít na paměti, že hlavní je vzdělávací proces, jeho plánování, využívání forem, metod a didaktických prostředků k dosažení vzdělávacích cílů. Dále je nutné přihlédnout $\mathrm{k}$ možnostem moderních informačních a komunikačních technologií, a to zejména v oblasti multimédií, simulací a virtuální reality, kdy je možné vzdělávací obsah přenášet on-line a to nejen $\mathrm{v}$ textové podobě, ale také formou, které může daleko více rozvíjet oblast psychomotorickou a afektivní. Proto se spíše kloníme k definici: ,e-learningem v tomto pojeti nebude předání dat na disketě nebo jen prečtení si informace $z$ Internetu bez jejího dalšiho cíleného zpracování. Naopak u složitějších kurzů jde o co nejširši využití metody, ,learning by doing“. Smateriály se pracuje, využívá se externich zdrojü, úkoly se tvoři, obhajuji, uplatňují vpraxi (dosažení nejvyšši hladiny vzdělávacích cílů). A k tomu patři bohaté rozvinutí skutečné tvořivé diskuse, poradenství atd. Takto stručně můžeme upozornit na atributy složitého a kvalitního e-learningového kurzu" (7).

V tomto pojetí byl tedy e-learning implementován i v podmínkách PdF UP Olomouc.

\section{LMS Unifor Live!}

Dalším prvkem, který je nutný pro efektivní realizaci distančních forem vzdělávání s využitím e-learningu je LMS. LMS je možné definovat jako: „Learning Management Systém - což znamená v překladu ř́dicí výukový systém". LMS tedy reprezentuje virtuální vyučovací prostředí, ve kterém se nacházejí výukové kurzy, zkušební testy, studijní instrukce, cvičební plány nebo diskusní fóra apod.

„LMS jsou aplikace, které v sobě integruji zpravidla nejrůznější on-line nástroje pro komunikaci a řizení studia (nástěnka, diskusní fórum, chat, tabule, evidence atd.) a zároven̆ zpřistupňuji studentům učební materiály či výukový obsah on-line nebo i off-line“ (9).

V podmínkách PdF UP Olomouc byl zvolen jako primární LMS systém Unifor Live!, který je používán pro realizaci všech distančních forem vzdělávání prostřednictvím e-learningu. Tento systém je definován jako: „systém pro ř́zené vzdělávání umožňující realizaci e-learningového vzdělávání na rüzných úrovních a podporované systémem propracovaných nástrojů. Z tohoto důvodu je LMS Unifor Live! vhodný pro velké množství institucí poskytujících distanční vzdèlávání (at’ již na úrovni komerční či nekomerční),, (10).

LMS Unifor se skládá z několika základních částí zaměřených na konkrétní skupiny uživatelů (10):

1. Studentské prostředí

2. Tutorská část

3. Komunikační nástroje

4. Další podpưrné nástroje

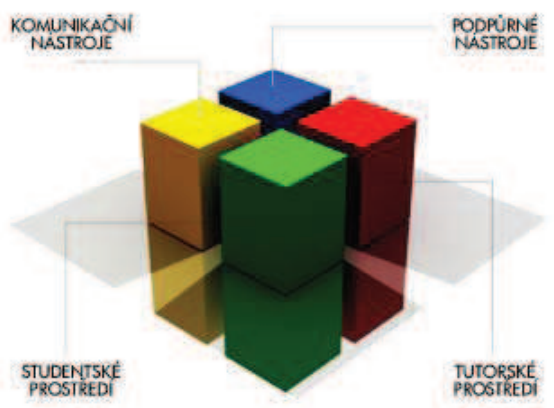

Obr. 1: Struktura LMS Unifor Live!

\section{Současná situace na PdF UP Olomouc}

I když byl model financování vysokých škol vždy velmi úzce svázán s počtem studentů, MŠMT ČR již několik let nemá tolik peněz na financování stále vyššího počtu studentů, a proto přistupuje $\mathrm{k}$ úpravě metodik tak, aby se podíl 
příspěvku studenty postupně snižoval a byl také navázán na vědecký výkon (11).

Jelikož tedy př́spěvek na studenta od roku 2004 nominálně nenarůstal (v porovnání s inflací se dokonce reálně snižoval), přistoupilo mnoho vysokých škol k restrukturalizaci svých studijních oborů, směrem ke kombinovaným formám studia, a ke zvýšení efektivnosti výukového procesu. Tento jev nastal na PdF UP Olomouc, což je patrné z níže uvedeného grafu.

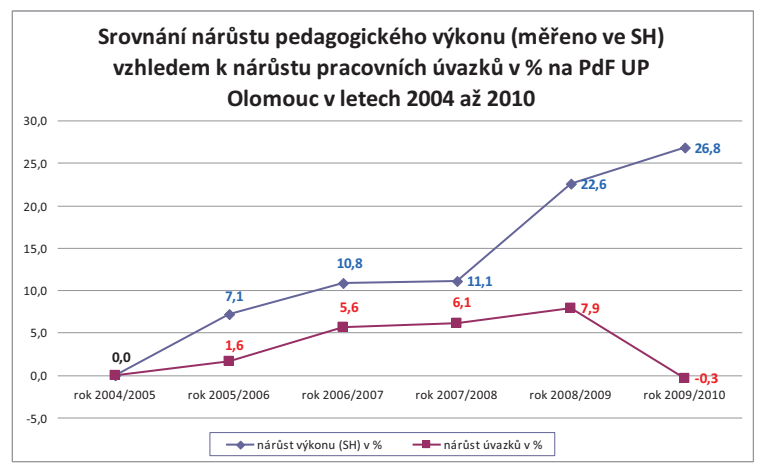

Graf 1: Porovnání náruistu pedagogického výkonu ve studentohodinách na PdF UP Olomouc.

Celkový výkon, jak je uvedeno i ve vlastním grafu byl vypočítán z takzvané ,studentohodiny“. Studentohodinu (SH) je možné definovat jako:

\section{$S H=$ počet studentů $x$ počet hodin výuky}

Tyto hodnoty jsou vypočítány na základě podkladů uvedených v systému studijní agendy STAG a to na predmětových akcích.

Jak je z výše uvedeného grafu patrné, výuková zátěž od roku 2004 na PdF UP Olomouc neustále stoupá, ale počet úvazků $\mathrm{z}$ dlouhodobého hlediska stagnuje, a v posledních letech dokonce klesá. Na základě tohoto zjiššení by bylo možné tvrdit, že nárůst pedagogického výkonu je realizován na úkor kvality poskytovaného vzdělávání. Toto tvrzení je možné vyvrátit na základě dalšího níže uvedeného grafu:

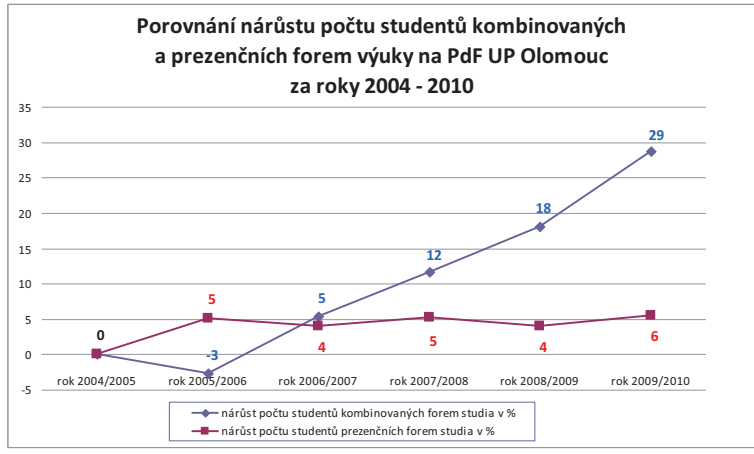

Graf 2: Porovnání nárůstu počtu studentů na PdF UP Olomouc.
$\mathrm{Z}$ uvedeného grafu je jasně patrné, že nárůst počtu studentů je daleko vyšší v kombinovaných formách studia na PdF UP Olomouc, než v prezenčních.

O kolik studentů, a $\mathrm{v}$ jaké struktuře se jedná je patrné z dalšího uvedeného grafu.

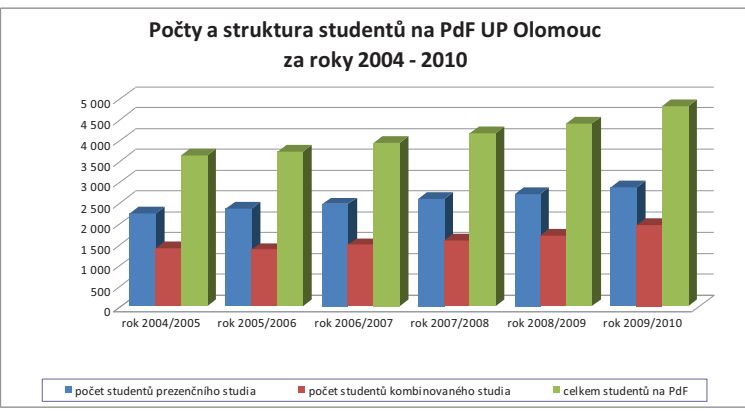

Graf 3: Počty a struktura studentů na PdF UP Olomouc.

Z výše uvedených dat je tedy možné odvodit, že zájem studentů o kombinované formy studia na PdF UP Olomouc neustále stoupají. Toto tvrzení je opět možné doložit grafem, ze kterého je patrný nárůst uchazečů o studium na PdF UP Olomouc a je také patrný vrůstající podíl uchazečů o kombinované formy studia.

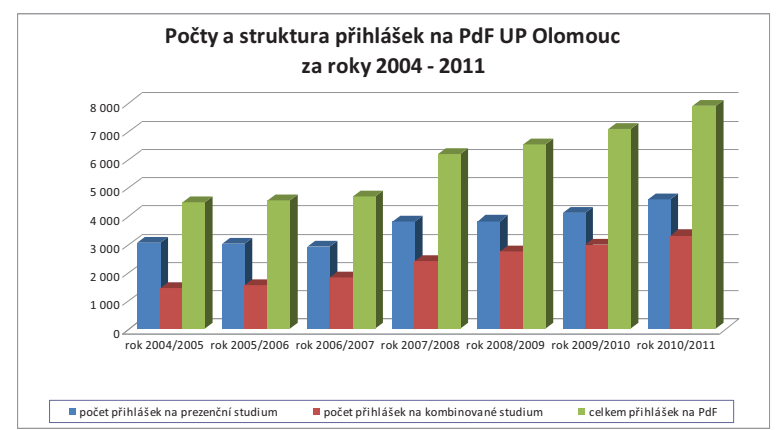

Graf 4: Počty a struktura uchazeču o studium na PdF UP Olomouc.

$\mathrm{Na}$ základě předložených údajů je možné konstatovat, že podíl kombinovaných forem výuky na PdF UP Olomouc každoročně vzrůstá a to nejen $\mathrm{z}$ důvodu většího zájmu uchazečů o tento typ studijních programů, ale také v důsledku zvyšování efektivity výukového procesu. Jak je dosahováno zvyšování efektivity výukového procesu, popisuje další kapitola.

\section{DiV a e-learning na PdF UP Olomouc}

Zvyšující se výuková zátěž je tedy důsledkem nejednotné politiky financování vysokých škol ze strany MŠMT ČR (11).

Zvyšování počtu studentů $\mathrm{v}$ prezenčních studijních programech již zřejmě není do 
budoucna možné, nebot' prezenční výuka musí být vázána na prostor a čas, je tudíž i časově velmi náročná a také kapacitně velmi těžko zabezpečitelná.

Možnost, jak řešit tento problém tedy nabízejí distanční způsoby vzdělávání, realizované prostřednictvím e-learningu a podpořené LMS systémy. Na níže uvedeném grafu je prezentována situace na PdF UP Olomouc v oblasti počtu a struktury vyučovaných disciplín.

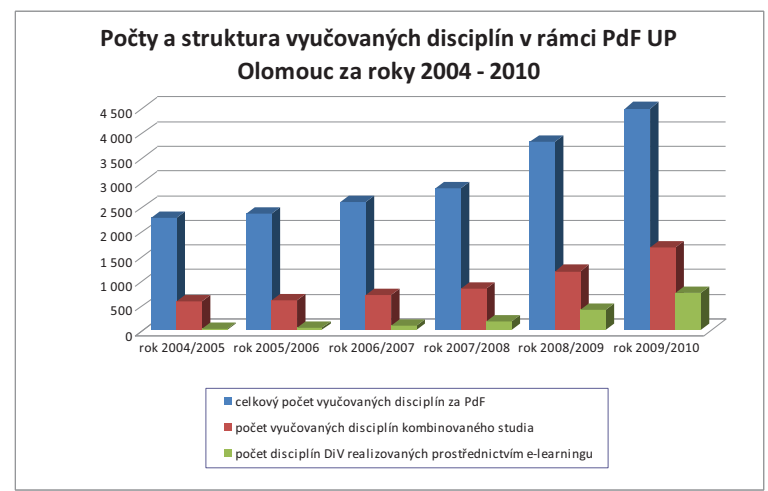

Graf 5: Počty a struktura vyučovaných disciplín na PdF UP Olomouc.

Jak je z grafu jasně patrné, celkový počet vyučovaných disciplín, $\mathrm{v}$ důsledku zvyšování výukové zátěže a tím otevírání nových studijních oborů, se každoročně zvyšuje. Toto zvyšování velmi razantně probíhá i u disciplín vyučovaných $\mathrm{v}$ rámci kombinovaných forem vzdělávání a u předmětů realizovaných distanční formou s využitím e-learningu. Kombinovaná forma výuky je totiž složena ze dvou částí:

- distanční,

- prezenční.

Tato kombinace distanční a prezenční výuky bývá v moderní literatuře označována jako Blended learning, který se „snaži kompenzovat některé dillči nevýhody eLearningu při plněni vzdèlávacích cílu kombinací s prvky standardni výuky, kdy je např́klad kombinován $v$ distančním studiu eLearningový kurz s úvodním či závěrečným seminářem nebo workshopem. Tento prístup je vhodný předevšim tam, kde cílová skupina neni zvyklá použivat moderní komunikačni nástroje, jako je chat, diskusní fórum, videokonference a podobne“" (12).

Tento princip realizace distančních forem studia na PdF UP Olomouc byl aplikován do praxe a na jeho základě je tedy od roku 2006 realizovány téměř všechny distanční výuky $\mathrm{v}$ rámci kombinovaných, ale i prezenčních částech studia.
Samozřejmostí ale je, že je studentům k dispozici široká paleta vzdělávacích studijních materiálů, které v tomto pojetí označujeme jako elektronické studijní opory či multimediální studijní opory (6). Specifikem těchto studijních materiálů je to, že jsou studentům dostupné pomocí LMS systému Unifor Live!, tím pádem mohou využít všech řídících, evaluačních či komunikačních složek tohoto systému, že obsahují vysoké procento multimediálních či simulačních prvků, které umožňují velmi vhodným způsobem rozvíjet mimo kognitivních cílů vzdělávání také psychomotorickou a afektivní složku.

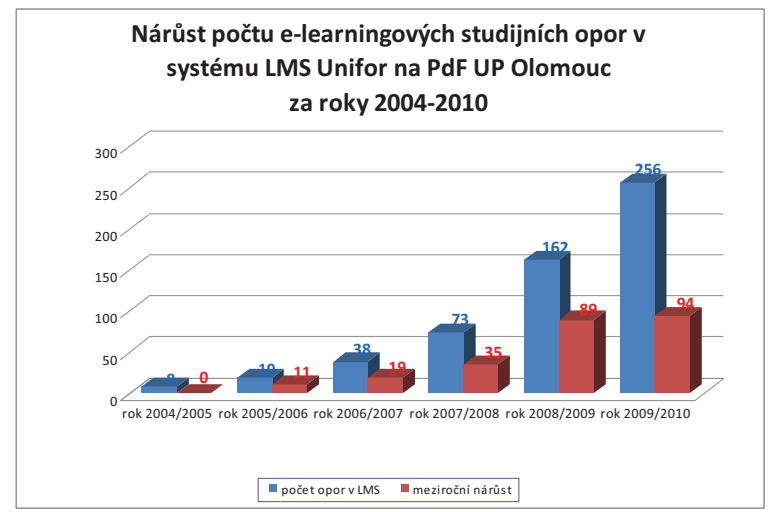

Graf 6: Nárůst počtu e-learningových studijnich opor na PdF UP Olomouc.

Uvedený graf tedy ukazuje, jakým tempem a v jakém rozsahu se zvyšuje počet těchto vzdělávacích materiálů ve sledovaném období.

\section{Závěr}

Pedagogická fakulta Univerzity Palackého v Olomouci od roku 2006 velmi cíleně podporuje snahy vedoucí k širšímu využití distančních forem výuky v kombinovaných, ale i prezenčních formách výuky, a to ve všech typech studijních programů (bakalářský, magisterský, doktorský).

Je možné konstatovat, že tato podpora přispěla ke zkvalitnění a rozšíření nabídky studijních programů realizovaných na $\mathrm{PdF}$ UP Olomouc, a tato tvrzení doložit řadou čísel, která byla získána na základě dlouhodobé analýzy vzdělávacích podmínek za využití e-learningu a LMS systému Unifor Live!

Samotný princip podpory distančních forma výuky vychází z těchto zásad a pravidel:

- jako primární způsob distančního vzdělávání je podporován e-learning,

- pro potřeby kombinovaných forem výuky je využíváno i prezenčních částí výuky 
(tutoriály, workshopy apod.) a to v pojetí blended learningu,

- LMS systém je důsledně využíván pro realizaci všech distančních forem výuky,

- je primárně podporován pouze jeden LMS systém, nebot' nedochází k trríštění finanční či jiné podpory,

- existuje ucelený soubor prováděcích norem, které každou část distančního vzdělávání přesně a jasně vymezují,

- byl vytvořen autorský nástroj MiniAware, který umožňuje autorům rychlou a snadnou tvorbu elektronických studijních opor.

Můžeme tedy konstatovat, že způsob podpory rozvoje distančních forem výuky s podporou LMS systému a e-learningu se v podmínkách PdF UP Olomouc plně osvědčil.

\section{Literatura}

[1] Evropský prostor vysokoškolského vzděláváni [on-line]. 19. 6. 1999. [cit. 1. 3. 2010]. Dostupné na World Wide Web

$<$ http://www.bologna.msmt.cz/files/DeklaraceBo logna.pdf $>$.

[2] Komuniké Konference ministrů odpovědných za vysoké školství [on-line]. 19. 9. 2003. [cit. 1.3. 2010]. Dostupné na World Wide Web < http://www.bologna.msmt.cz/files/KomunikeBerl in.pdfs.

[3] Pravidla pro poskytování př́spěvků a dotací veřejným vysokým školám Ministerstvem školství, mládeže a tělovýchovy podle zákona č. 111/1998 Sb., o vysokých školách a o změně a doplněni dalšich zákonu (zákon o vysokých školách), ve znění pozdějšich předpisů - pro rok 2006 [online]. 24. 2. 2006. [cit. 1. 3. 2010]. Dostupné na World Wide Web $<$ http://aplikace.msmt.cz/vysokeskoly/financovan iVS/Pravidla 2006 pro VVS Vestnik.htm>.

[4] VINŠ, V. a kol. Akreeditace jednotlivých forem studia studijních programů vysokých škol

[on-line]. 19. 6. 2000. [cit. 1. 4. 2010]. Dostupné na World Wide Web

$<$ http://www.csvs.cz/konference/lisalova_cd/Sbor nik\%20anotaci/Vins.pdf $>$.

[5] KLEMENT, M., ŠTENCL, J. Směrnice děkanky 1S/2008 - Použití distančních forem výuky v rámci PdF UP [on-line]. 28. 2. 2008. [cit. 1. 4. 2010]. Dostupné na World Wide Web $<$ http://www.upol.cz/fileadmin/user_upload/PdF/ prov-normy-dekana/1S2008.doc>.
[6] KLEMENT, M., ŠTENCL, J. Směrnice děkanky 2S/2008 - Realizace distančních forem výuky na PdF UP [on-line]. 28. 2. 2008. [cit. 1. 4. 2010]. Dostupné na World Wide Web $<$ http://www.upol.cz/fileadmin/user_upload/PdF/ prov-normy-dekana/2S2008.doc>.

[7] EGER, L., DVOŘÁKOVÁ, E. Centrum celoživotního vzdělávání. 1. vyd., Ostrava: Regionální centrum celoživotního vzdělávání VŠB - Technická univerzita Ostrava, 2003. 70 s. ISBN 80-248-0505-7. Dostupné na World Wide Web

$<\mathrm{http}$ ://rccv.vsb.cz/docs/centrum celozivotniho vzdelavani.doc $>$.

[8] PRŮCHA, J, WALTEROVÁ, E., MAREŠ, J. Pedagogický slovník. Praha, Portál 2001. 328 s. ISBN 80-7178-252-1.

[9] Wikipedie, Otevřená encyklopedie [online]. 1995, 15. 11. 2008 [cit. 1. 4. 2010]. Dostupné na World Wide Web: $<\mathrm{http}$ //cs.wikipedia.org/wiki/Learning_Manage ment_System>.

[10] LMS Unifor Live! - základní informace. [online], [cit. 1. 4. 2010]. Dostupné na World Wide Web:

$<$ http://www.lmsunifor.com/index.php/lmsunifor-live/zakladni-informace>.

[11] Pravidla pro poskytování př́spěvku a dotaci veřejným vysokým školám Ministerstvem školství, mládeže a tělovýchovy - pro rok 2010 [on-line]. 10. 2. 2010. [cit. 7. 4. 2010]. Dostupné na World Wide Web http://www.msmt.cz/uploads/soubory/vysoke_sk oly/598_2010_33_Pravidla_pro_poskytovani_pri spevku_a_dotaci_VVS_SCHVALENA_10_2_10 .doc $>$.

[12] Wikipedie, Otevřená encyklopedie - Blended learning [online]. 14. 3. 2010. [cit. 7. 4. 2010]. Dostupné na World Wide Web: $<$ http://cs.wikipedia.org/wiki/Blended_learning $>$.

PhDr. Milan Klement, Ph.D.

PaedDr., PhDr. Jiř́i Dostál, Ph.D.

Katedra technické a informační výchovy

Pedagogická fakulta UP

Žižkovo nám. č. 5

771 40, Olomouc, $\check{C} R$

Tel: +420 $585635811,+420585635818$

E-mail: milan.klement@upol.cz,

j.dostal@upol.cz

Www pracoviště: www.kteiv.upol.cz 